\title{
MANUFACTURE AND PERFORMANCE EVALUATION OF A LOCAL COMPOST SCREENING UNIT FOR MAXIMUM PRODUCT QUALITY
}

\author{
Mariam, M. M.*; A. F. Abdel Mottaleb** A.A. Derbala***and T.Z. Fouda ****
}

\begin{abstract}
Experiments were carried out to manufacture and evaluate the performance of a small scale screening unit suitable for compost cleaning. The machine performance was studied as a function of change in material feed rate, sieve speed, sieve inclination angle and compost moisture content. Performance evaluation of the manufactured machine was carried out in terms of machine productivity, separating efficiency compost losses, cleaning efficiency, required power, energy requirements and criterion cost.

The experimental results reveal that compost losses as well as criterion costs were minimum while separating and cleaning efficiencies were maximum under the following conditions:

- The use of the developed compost cleaning unit.

- Operate the developed machine at a sieve speed of between 30 to 40 rpm $(1.57$ to $2.1 \mathrm{~m} / \mathrm{s})$.

- Operate the developed machine at a sieve inclination angle of between 10 to 15 degrees.

- Clean compost at a moisture content of about $40 \%$.

- Operate the developed machine at a feed rate of between 3.0 to $4.5 \mathrm{Mg} / \mathrm{h}$.
\end{abstract}

\section{INTRODUCTION}

Agricultural policy depends on the successful technology through mechanizing the agricultural processes. Field crop residues are considered one of the most critical which face the Egyptian farmers. Accumulation of these residues in large quantities results not only in deterioration of the environment but also in a loss of potentially valuable material. Manuring with these residues through composting is a promising route, especially with the increase in fertilizer price.

\footnotetext{
* Grad. St., Agric. Eng. Dept., Fac. Of Agric., Tanta Univ.

** Senior Res., Agri. Eng. Res. Inst. (A.R.C.), Egypt.

*** Assoc. Prof. and Head Of Agric. Eng. Dept., Fac. Of Agric., Tanta Univ. ***** Prof. and Vice Dean for Environment Sector, Fac. Of Agric., Tanta Univ.
} 
Composting is the biological reduction of organic wastes to humus. The good composting structure depends on the correct mixing and turning of materials as well as, after maturity the correct screening of the produced compost.

Screening improves the quality of the produced compost for sale or use by removing unwanted objects such as rocks, metals, clumps, and other trash.

Klenin et al. (1985) mentioned that cleaning machines which separate the principle product from coarse impurities are known as wild oat separators (cylindrical screens). The working of the cylindrical screens involves the following operations: picking up small particles of the product by its cells and lifting the particles and throwing them into the receiver troughs. These operations are governed by the kinematic operating conditions of the machine and its geometric parameters .They added that sieves are selected according to their function. Various types of sieves manufactured are: sieves to separate ears and other impurities from grain, fine mesh sieves to shift fine impurities and grading sieves to separate grain into various fractions of different thickness or length.

Robert (1992) stated that when choosing screens, the important characteristics to consider are the screen opening size, capacity, effectiveness, cost, and susceptibility to blinding. For screening compost, the screen openings should be 0.25 to 0.5 inch $(0.63$ to $1.27 \mathrm{~cm}$ ), depending upon the material to be separated out and the end use for the compost. Smaller openings provide better separation but, for a given screen, reduce the capacity and increase the chances of blinding. The screen effectiveness decreased when particles larger than desired pass through the screen. Both effectiveness and capacity are influenced by the material feed rate as well as the screen opening size. Screens perform better with dryer material. To screen compost without excessive blinding, the moisture content should be less than $50 \%$ and it is preferably less than $45 \%$.

William (2000) stated that the acceptable quantities of foreign matter in compost have been a subject of some debate, but generally there is greater agreement on these standards. Normally, stones are distinguished from non-decomposable "foreign matter" which includes glass, plastic 
and metal. The limits pertain to a percentage at a specific screen size. $\mathrm{He}$ classified foreign matter in compost into two parts: Stones \% of dry weight and Man-Made Foreign Matter (glass, plastic, metal), as\% of dry weight.

Page et al. (2005) determined whether passing compost through a ball screen, an $18.75 \mathrm{~mm}$ trommel screen, or twice through an $18.75 \mathrm{~mm}$ trommel screen lead to the lowest levels of foreign would matter (undesirable material remaining in the final product) in the municipal solid waste compost. They found that the overall percentage of foreign matter ranged from $1.8 \%$ for the ball screen, to $2.72 \%$ for one pass with a trommel screen, and $1.75 \%$ for two passes with the trommel screen. Therefore, processing with the ball screener or two passes with the trommel screener created compost with a lower percentage of foreign matter.

So, such care had to be taken to design, manufacture and develop a simple low cost machine from local material to be used for compost cleaning taking into consideration its effectiveness.

There are many factors that control the performance of compost cleaning machine. These factors can be divided into two sections: machine and material. Machine variables include sieve speed, sieve inclination angle, screen opening size and feeding rate. Moreover, material variables such as compost moisture content and degree of compost maturity are considered critical factors. The mentioned factors affect directly on the compost losses, energy requirements, efficiency, productivity, and the total operational cost.

\section{So, the objectives of this study are to:}

- Manufacture a local compost screening unit from low cost local material to be suitable for Egyptian farms.

- Optimize some different operating parameters (material feed rate, sieve speed, sieve inclination angle and compost moisture content) affecting the performance of the manufactured machine.

\section{MATERIAL AND METHOD}

Experiments were carried out through years of 2009 and 2010 at Super Bio Company for Organic Fertilizers, El Senbelawen farm, Dakahlia Governorate to manufacture and evaluate the performance of a small scale screening unit suitable for compost cleaning. 


\section{Materials}

\subsection{Compost}

Crop residues (especially rice straw) were used as a raw material for producing compost. Poultry and live-stock manure were also used to accelerate composting process. Added to that finished compost was used as a supply of microorganisms.

\subsection{The local compost screening machine}

A local screening machine, suitable for compost cleaning, was manufactured from low cost, local material to overcome the problems of high power and high cost requirements under the use of the imported machines. The developed machine, which consists mainly of screening device and feeding device, is shown in Figs 1,2.

\subsubsection{The screening device}

The screening device separates the principle product (clean compost) from coarse impurities and un composted material. The screening device consists mainly of power source, transmission system, machine frame and cleaning unit. The developed machine was powered by an electric motor $3.68 \mathrm{~kW}(5.00 \mathrm{hp})$ at a rated speed of $1450 \mathrm{rpm}$.

The machine shaft of the developed machine is operated by means of machine pulley (350 $\mathrm{mm}$ diameter) and belt powered from the electric motor pulley (100 $\mathrm{mm}$ diameter). The power is transmitted from the motor pulley to the machine shaft with different speed ratios.

The machine frame, which carries all the screening device parts, is made of steel $\mathrm{L}$ section of $16 \mathrm{~mm}$ thickness. The frame is carried on 4 legs made of the same steel, two legs on each side, with a longitudinal space between them of $300 \mathrm{~cm}$.

The cleaning unit consists of a rotating shaft, a cleaning drum and a drum cover. The rotating shaft is made of iron steel with $70 \mathrm{~mm}$ diameter. The shaft is supported by two bearings. The shaft is operated by means of pulley ( $350 \mathrm{~mm}$ diameter) and belt powered from the electric motor. The shaft length is $2800 \mathrm{~mm}$. 
The drum is supported on the rotating shaft by means of iron bars and bolts so as to take its motion. The cleaning drum was manufactured from iron sheet of $8 \mathrm{~mm}$ thickness. The cleaning drum length is $2600 \mathrm{~mm}$ while its diameter is $1000 \mathrm{~mm}$. The cleaning drum consists of two parts. The first part is $2000 \mathrm{~mm}$ in length perforated with round holes of $13 \mathrm{~mm}$ (2400 holes $/ \mathrm{m}^{2}$ ) to allow clean compost to be separated and passing through the holes and collected from the out let of the screened compost, while the second part is $600 \mathrm{~mm}$ in length without holes to collect both impurities and un composted material to be delivered from the out let of the un wanted materials. The drum is also provided by screw bar to be tilted relating to the horizontal axis with an inclination angle.

The drum cover is fixed around the cleaning drum and has a gate from below to deliver the screened compost through it and at the same time prevent delivering screened compost from the sides. The drum cover was manufactured from iron sheet of $4 \mathrm{~mm}$ thickness.

\subsubsection{The feeding device}

The feeding device is used to control the compost feeding rate passing to the cleaning unit. The feeding device consists mainly of four main parts power source, transmission system, feeding device frame and the rubber conveyor belt. The feeding device was powered by an electric motor 2.21 $\mathrm{kW}(3.0 \mathrm{hp})$ at a rated speed of $1450 \mathrm{rpm}$.

The belt of the feeding device is operated by means of drive pulley ( 320 $\mathrm{mm}$ diameter and $700 \mathrm{~mm}$ width) and belt powered from the electric motor pulley (100 $\mathrm{mm}$ diameter). The power is transmitted from the motor pulley to the drive pulley with different speed ratios.

The frame consists of two sides with a lateral space between them of 180 $\mathrm{cm}$. Its height is $185 \mathrm{~cm}$ from the front side, which the drive pulley is fixed. While its height is $125 \mathrm{~cm}$ from the back side, which the driven pulley is fixed. The longitudinal distance between the front and the back sides is $273 \mathrm{~cm}$. This frame shape makes the oblique angle with horizontal is about 20 degrees.

The conveyor flat belt with dimensions of $300 \mathrm{~cm}$ in length, $65 \mathrm{~cm}$ in width and $0.4 \mathrm{~cm}$ in thickness was constructed on drive and driven pulleys. The total length of the conveyor flat belt is $8.5 \mathrm{~m}$. 


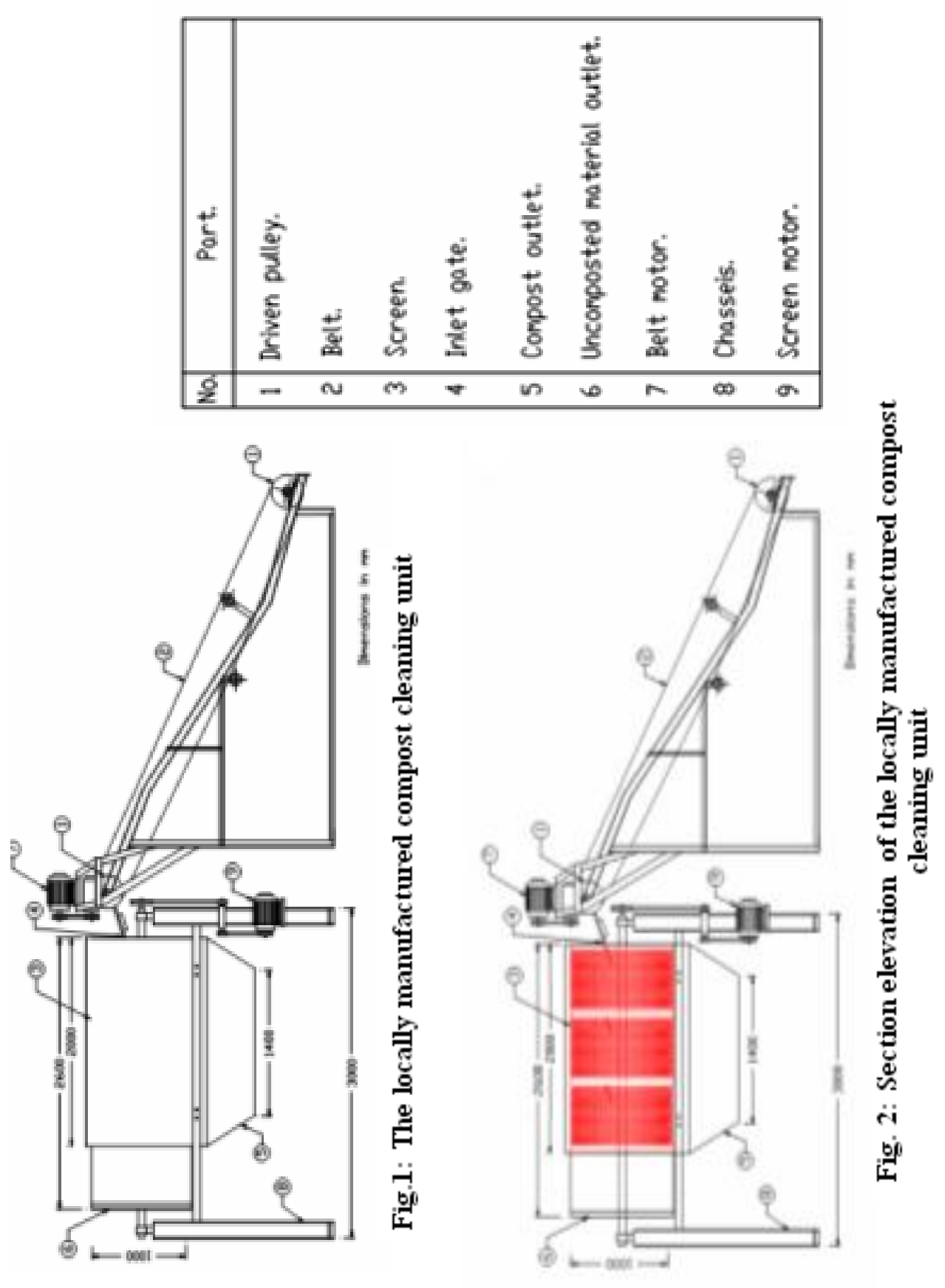




\section{2- Methods}

Experiments were carried out to evaluate the performance of the developed screening unit to optimize the values of the main operating parameters during compost cleaning.

\subsection{Experimental conditions}

The performance of the developed machine was experimentally measured under the following parameters:

- Four different sieve speeds (20,30, 40 and $50 \mathrm{rpm}$ which

Corresponding to $1.05,1.57,2.1$ and $2.45 \mathrm{~m} / \mathrm{s}$ ).

- Four different sieve inclination angles $(5,10,15$ and $20 \mathrm{deg})$.

- Four different compost moisture contents (35, 40, 45, and 50\%).

- Four different compost feeding rates $(1.5,3.0,4.5$ and $6.0 \mathrm{Mg} / \mathrm{h})$.

\subsection{Measurements and determinations}

Evaluation of the performance of cleaning machine was based on the following indicators:

\subsubsection{Machine productivity}

Machine productivity was determined by the following equation:

$$
\mathrm{M}_{\mathrm{P}}(M g / h)=\frac{\mathrm{W}_{S}}{\mathrm{t}}
$$

\section{Where:}

$\mathrm{M}_{\mathrm{p}}$ - Machine productivity, $\mathrm{Mg} / \mathrm{h}$,

$\mathrm{W}_{\mathrm{S}}$ - Mass of screened compost sample collected

from the out let of the screened compost, $\mathrm{Mg}$,

$\mathrm{t}$ - The time consumed to clean the sample, $\mathrm{h}$.

\subsubsection{Separating efficiency}

Separating efficiency was obtained as a percentage between screened compost delivered from the compost output gate and input unscreened compost sample. The percentage of cleaning efficiency was calculated by using the following equation:

$$
\eta_{\mathrm{S}}(\%)=\frac{\mathrm{W}_{\mathrm{S}}}{\mathrm{W}_{\mathrm{t}}} \times 100
$$

\section{Where:}

$\eta_{\mathrm{S}}$ - Separating efficiency, \%, 
$\mathrm{W}_{\mathrm{t}}$ - Mass of input unscreened compost sample delivered to the cleaning unit, $\mathrm{kg}$.

\subsubsection{Compost losses percentage}

Compost losses were obtained by collecting the amount of the clean compost which delivered from the outlet gate of both impurities and the un matured compost. The percentage of compost losses was calculated by using the following equation:

Compost losses percentage $(\%)=\frac{\mathrm{W}_{\mathrm{L}}}{\mathrm{W}_{\mathrm{t}}} \times 100$

\section{Where:}

$\mathrm{W}_{\mathrm{L}}$ - Mass of the clean compost which delivered from the outlet gate of both impurities and the un matured compost per unit time, $\mathrm{kg}$.

\subsubsection{Cleaning efficiency}

Cleaning efficiency was obtained as a percentage between the amount of the screened compost delivered from the compost output gate and the amount of the screened compost delivered from the same gate plus the amount of the clean compost which delivered from the outlet gate of both impurities and the un matured compost. The cleaning efficiency was calculated by using the following equation (Roth et al, 1975):

$$
\eta_{C L}(\%)=\frac{\mathrm{W}_{\mathrm{S}}}{\mathrm{W}_{\mathrm{S}}+\mathrm{W}_{\mathrm{L}}} \times 100
$$

\section{Where:}

$\eta_{\mathrm{CL}} \quad$ - Cleaning efficiency, $\%$,

\subsubsection{Required power}

The following formula was used to estimate the motor power (Kurt, 1979): $\mathrm{P}=\sqrt{3} \times \cos \varphi \times \mathrm{I} \times \mathrm{V} / 1000$

\section{Where:}

$\mathrm{P}$ - Power required, $\mathrm{kW}$,

I - Current intensity, Ampere,

$\mathrm{V}$ - Voltage, $(380 \mathrm{~V})$,

$\cos \varphi=0.7$ 


\subsubsection{Energy requirements}

The energy requirements for the cleaning operation can be calculated as follows:

Energy requirements $(\mathrm{kW} \cdot \mathrm{h} / \mathrm{Mg})=\frac{\text { Required power }}{\text { Machine productivity }}$

\subsubsection{Criterion cost}

The criterion cost (L.E./Mg) required for the cleaning operation was estimated using the following equation (Awady et al., 1982):

\section{Criterion cost $=$ operational cost + compost losses cost}

\section{Where:}

Operational cost $(\mathrm{L} . \mathrm{E} . / \mathrm{Mg})=\frac{\text { Machine hourly cost }}{\text { Machine productivity }}$

The machine cost (Hourly cost) was determined by using the following equation (Awady et al., 1978):

$$
\mathrm{C}=\frac{\mathrm{p}}{\mathrm{h}}\left(\frac{1}{\mathrm{a}}+\frac{\mathrm{i}}{2}+\mathrm{t}+\mathrm{r}\right)+(\mathrm{W} . \mathrm{e})+\frac{\mathrm{m}}{144}
$$

\section{Where:}

C - Machine cost, L.E. /h, $\quad$ P - Price of machine, L.E.,

$\mathrm{h}$ - Yearly working hours, h/year, a - Life expectancy of the machine, $h$,

$\mathrm{i}$ - Interest rate/year, $\quad \mathrm{t}$ - Taxes, over heads ratio,

$\mathrm{r}$ - Repairs and maintenance ratio, W- Power of motor in kW,

e - Hourly cost/kW.h, $\quad \mathrm{m}$ - The monthly average wage, L.E.,

144 - Reasonable estimation of monthly working hours.

\section{RESULTS AND DISCUSSION}

The discussion will cover the obtained results under the following heads:

\section{Effect of some operating parameters on machine productivity and separating efficiency}

Concerning the effect of sieve speed on both machine productivity and separating efficiency, results obtained show that increasing sieve speed increased both machine productivity and separating efficiency up to 40 $\mathrm{rpm}$, any further increase in sieve speed up to $50 \mathrm{rpm}$ machine productivity and separating efficiency will decrease (Fig. 3). 
Relating to the effect of sieve inclination angle on both machine productivity and separating efficiency, the obtained results show that increasing sieve inclination angle increased both machine productivity and separating efficiency up to 15 degrees, any further increase in sieve inclination angle up to 20 degrees machine productivity and separating efficiency will decrease (Fig. 3).

Referring to the effect of compost moisture content on both machine productivity and separating efficiency, results show that increasing compost moisture content increased both machine productivity and separating efficiency up to $40 \%$, any further increase in compost moisture content up to $50 \%$ machine productivity as well as separating efficiency will decrease (Fig. 3) .

As to the effect of compost feed rate on both machine productivity and separating efficiency, the machine productivity increased by increasing feed rate because of the increase of compost flow on the sieve surface at the same time unit resulting in more separated compost. The same behavior was noticed with the separating efficiency except for the feed rate of $6.0 \mathrm{Mg} / \mathrm{h}$ due to the high increase in compost losses at high feed rates (Fig. 3).

\section{Effect of some operating parameters on compost losses and cleaning efficiency}

Considering the effect of sieve speed on both compost losses and cleaning efficiency, the results show that compost losses vary inversely with sieve speed (in the range from 20 to $40 \mathrm{rpm}$ ). It is clear that compost losses were significantly decreased by increasing sieve speed up to 40 rpm, any further increase in sieve speed up to $50 \mathrm{rpm}$ compost losses will increase. While the vice versa was noticed with the cleaning efficiency, which increased by increasing sieve speed up to $40 \mathrm{rpm}$, then decreased by the further increase in sieve speed up to $50 \mathrm{rpm}$ (Fig.4).

Regarding the effect of sieve inclination angle on both compost losses and cleaning efficiency, results obtained show that increasing sieve inclination angle decreased compost losses up to 15 degrees, any further increase in sieve inclination angle up to 20 degrees, compost losses will increase. While the vice versa was noticed with the cleaning 

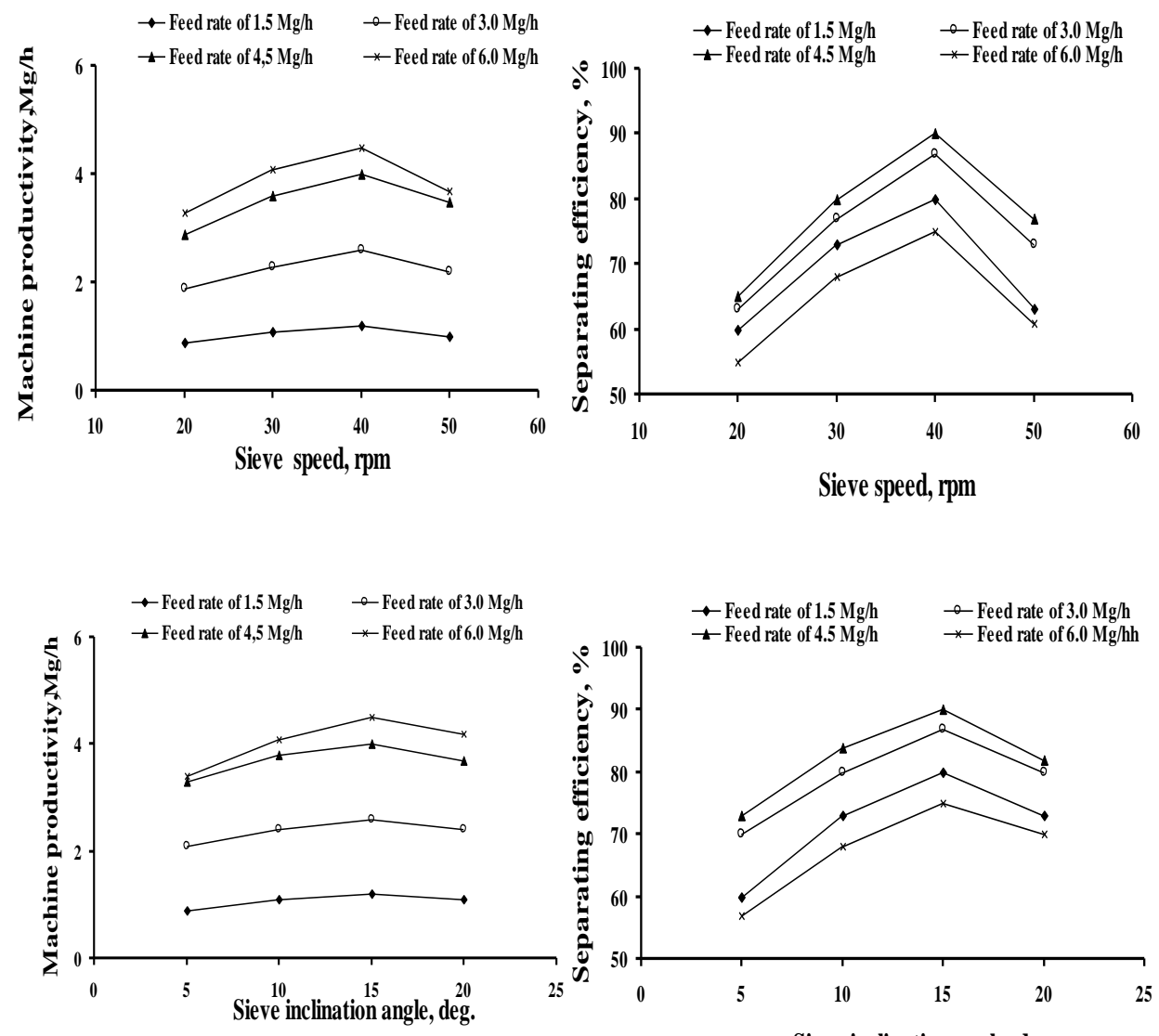

Sieve inclination angle, deg.


Fig. 3: Effect of some operating parameters on machine productivity and separating efficiency 


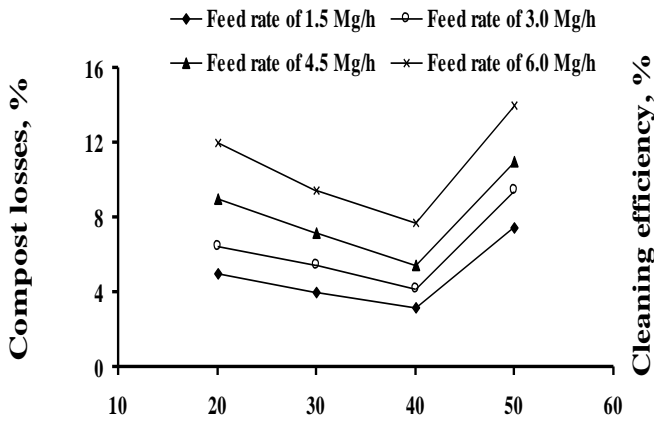

Sieve speed, $\mathrm{m} / \mathrm{s}$

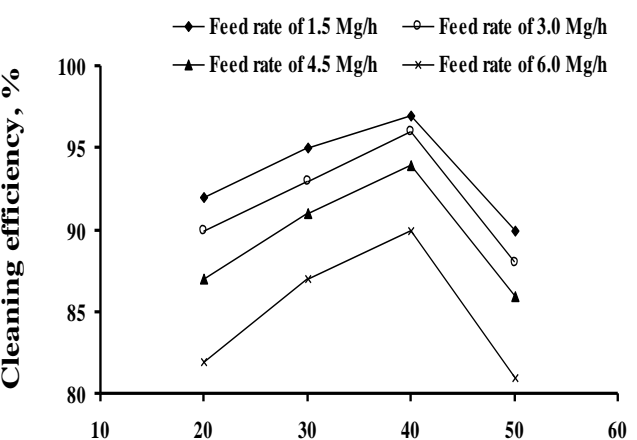

Sieve speed,m/s

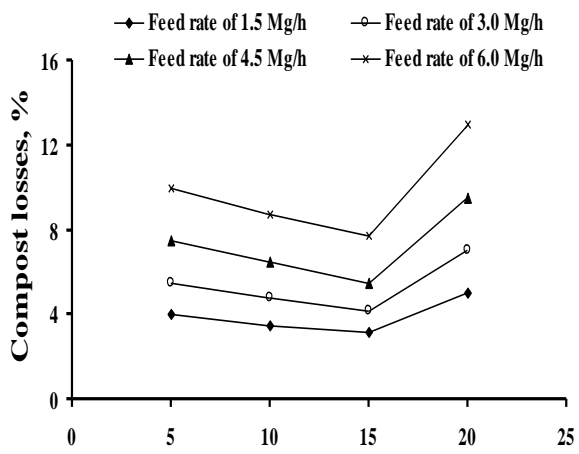

Sieve inclination angle, deg.



Compost moisture content, \%

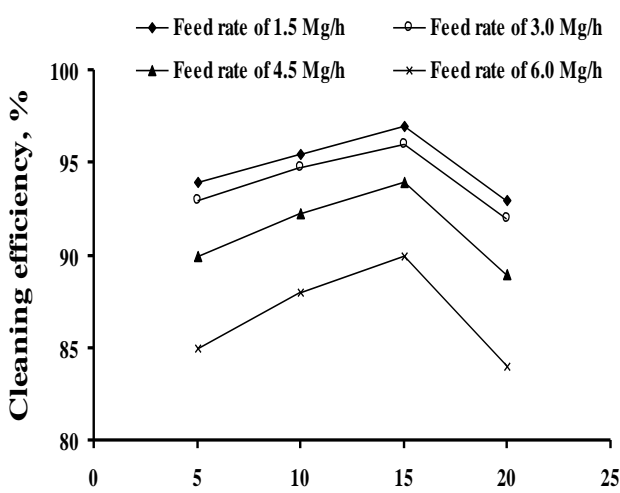

Sieve inclination angle, deg.

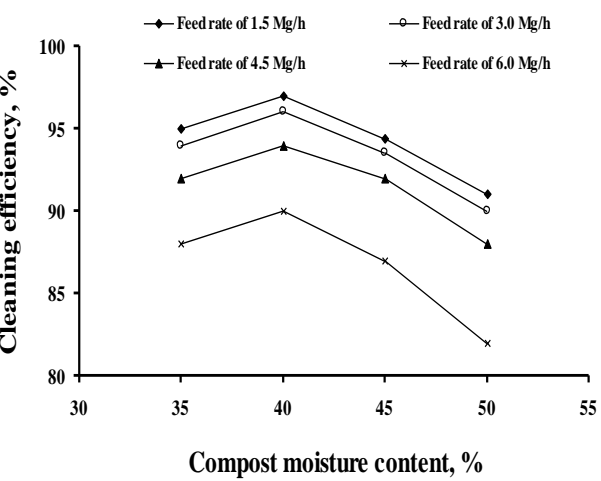

Fig. 4: Effect of some operating parameters on compost losses and cleaning efficiency 
efficiency, which increased by increasing sieve inclination angle up to 15 degrees, then decreased by the further increase in sieve inclination angle up to 20 degrees (Fig. 4).

With regard to the effect of compost moisture content on both compost losses and cleaning efficiency, the obtained results show that total compost losses vary inversely with compost moisture content. It is clear that compost losses were significantly decreased by increasing compost moisture content up to $40 \%$. Any further increase in compost moisture content up to $50 \%$, compost losses will increase. While the vice versa was noticed with the cleaning efficiency, which increased by increasing compost moisture content up to $40 \%$, then decreased by the further increase in compost moisture content up to $50 \%$ (Fig. 4).

As to the effect of compost feed rate on both compost losses and cleaning efficiency, compost losses increased while cleaning efficiency decreased by increasing feed rate because of the increase of compost thickness on the sieve surface, so most of compost will leave the sieve with impurities from the impurities exit (Fig. 4).

\section{Effect of some operating parameters on power and energy requirements}

Concerning the effect of sieve speed on power and energy requirements, results obtained show that increasing sieve speed increased the required power. While the same data show that the energy requirements vary inversely with sieve speed. It is clear that energy requirements were decreased by increasing sieve speed up to $40 \mathrm{rpm}$. Any further increase in sieve speed up to $50 \mathrm{rpm}$, energy requirements will increase (Fig. 5).

Regarding the effect of sieve inclination angle on power and energy requirements, the obtained results show that increasing sieve inclination angle decreased the required power. While the same data show that the energy requirements vary inversely with sieve inclination angle. It is clear that energy requirements were decreased by increasing sieve inclination angle up to 15 degrees. Any further increase in sieve inclination angle up to 20 degrees, energy requirements will increase (Fig. 5). 


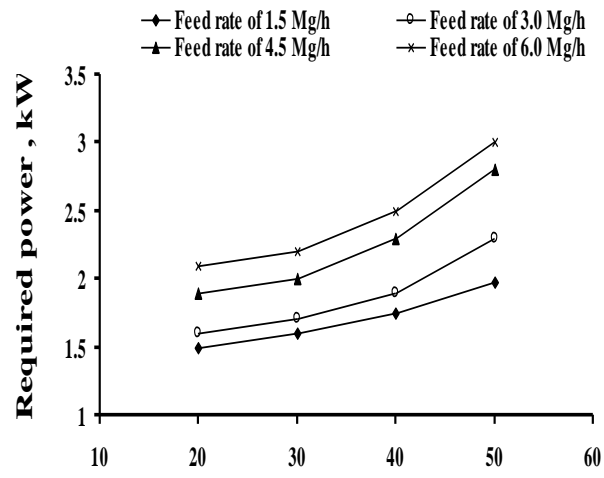

Sieve speed, rpm

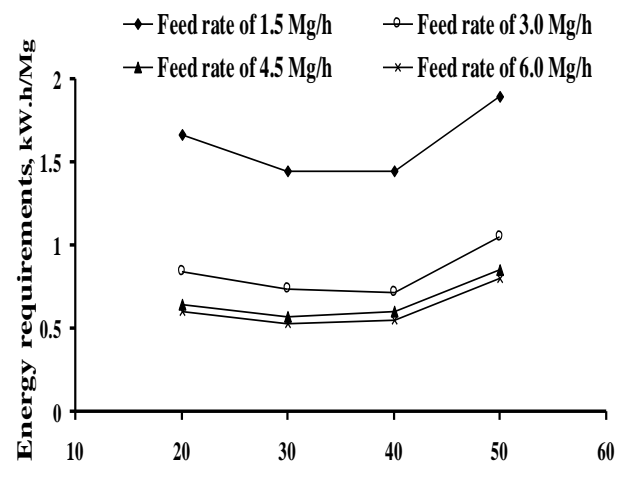

Sieve speed, rpm

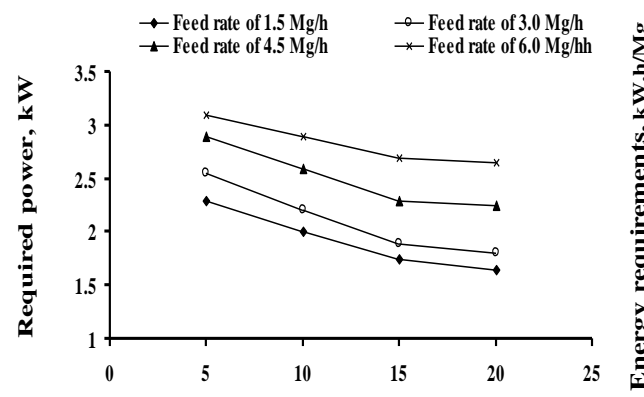

Sieve inclination angle, deg.



Sieve inclination angle, deg.
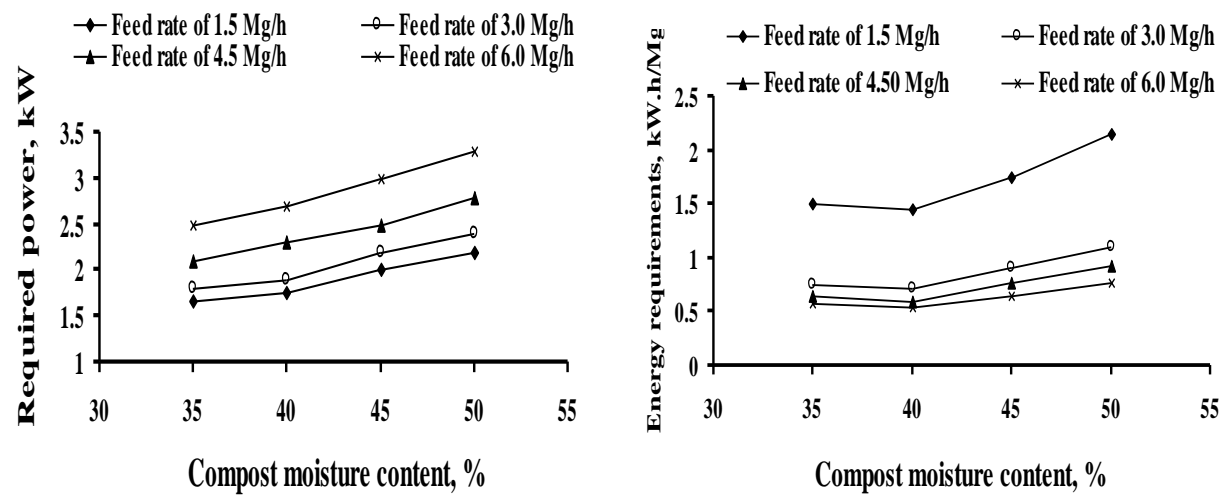

Fig. 5: Effect of some operating parameters on required power and energy requirements 
Relating to the effect of compost moisture content on power and energy requirements, the obtained results show that increasing compost moisture content increased the required power. While the same data show that the energy requirements vary inversely with compost moisture content. It is clear that energy requirements were decreased by increasing compost moisture content up to $40 \%$. Any further increase in compost moisture content up to $50 \%$, energy requirements will increase (Fig. 5).

As to the effect of compost feed rate on power and energy requirements, the required power increased by increasing compost feed rate because of the increase of compost flow on the sieve surface at the same time unit which represents extensive load on the sieve shaft resulting in more power (Fig. 5).

\section{Effect of some operating parameters on operational and criterion costs}

Considering the effect of sieve speed on both operational and criterion costs, results obtained show that increasing sieve speed decreased both operational and criterion costs up to $40 \mathrm{rpm}$, any further increase in sieve speed up to $50 \mathrm{rpm}$ operational and criterion costs will increase (Fig. 6).

Relating to the effect of sieve inclination angle on both operational and criterion costs, results obtained show that increasing sieve inclination angle decreased both operational and criterion costs up to 15 degrees, any further increase in sieve inclination angle up to 20 degrees operational and criterion costs will increase (Fig. 6).

Regarding the effect of compost moisture content on both operational and criterion costs, results obtained show that increasing compost moisture content decreased both operational and criterion costs up to $40 \%$, any further increase in compost moisture content up to $50 \%$, operational and criterion costs will increase (Fig. 6).

On the other hand, operational cost decreased by increasing compost feed rate due to the increase in machine productivity. While criterion cost was found to decrease by increasing feed rate from 1.5 to 3.0 
$\mathrm{Mg} / \mathrm{h}$ because the rate of increase in hourly cost is less than the rate of increase in machine productivity. Any further increase in feed rate more than $3.0 \mathrm{Mg} / \mathrm{h}$ up to $6.0 \mathrm{Mg} / \mathrm{h}$, criterion cost was found to increase (Fig. 6).
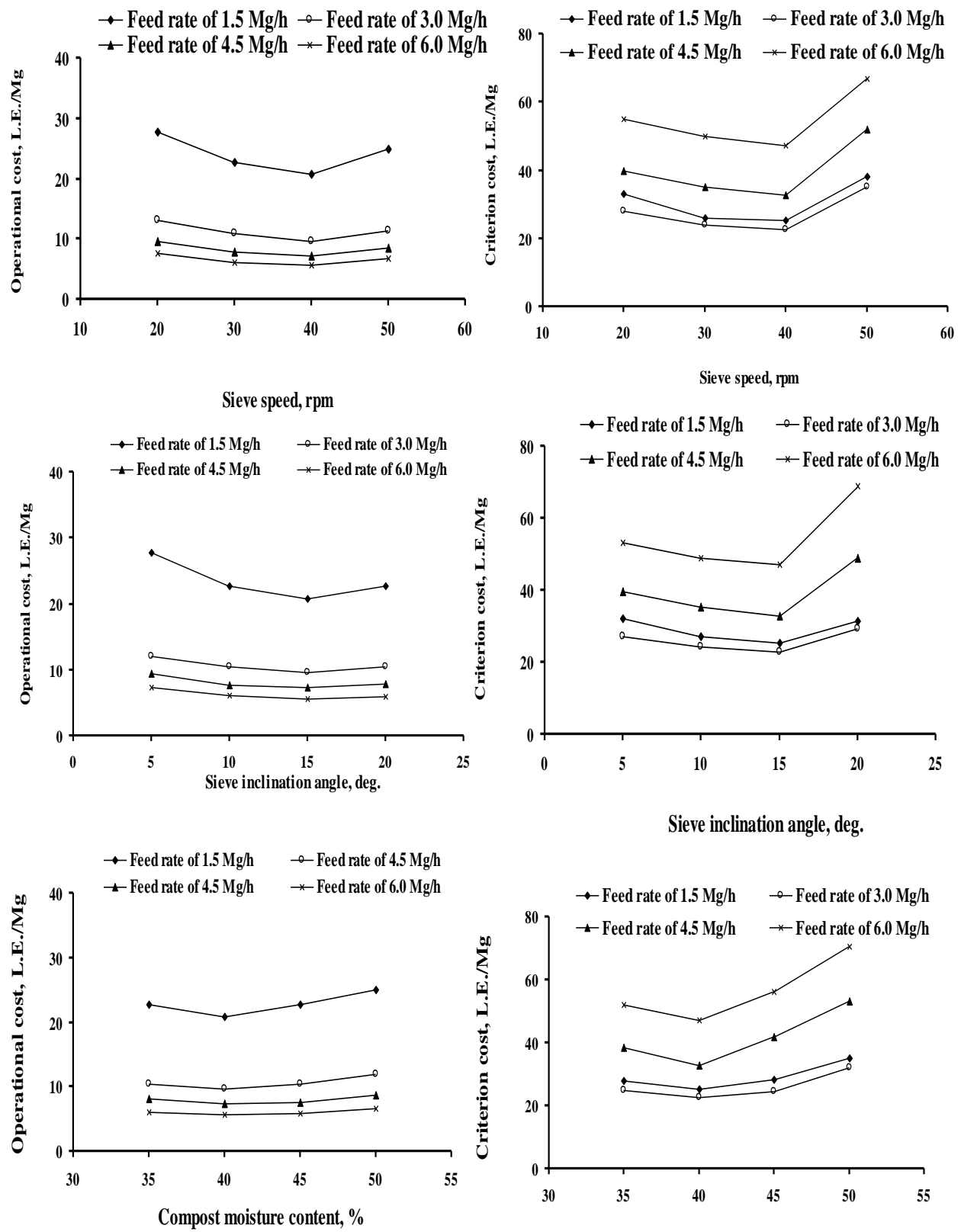

Sieve inclination angle, deg.

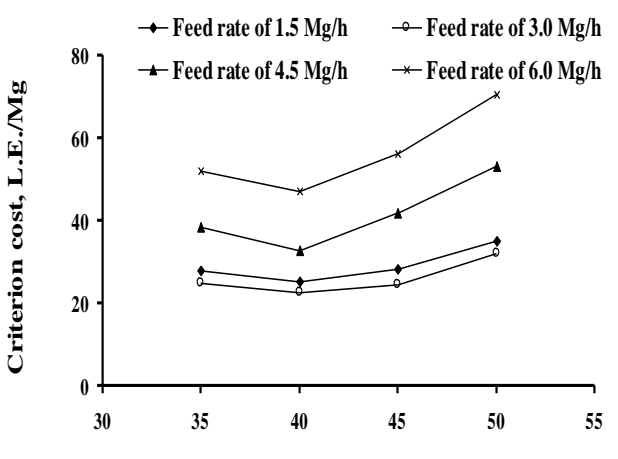

Fig. 6: Effect of some operating parameters Compost moisture content, \% on operational and criterion costs 


\section{CONCLUSIONS}

The experimental results reveal that compost losses as well as criterion costs were minimum while separating and cleaning efficiencies were maximum under the following conditions:

- Operate the developed machine at a sieve speed of between 30 to $40 \mathrm{rpm}(1.57$ to $2.1 \mathrm{~m} / \mathrm{s})$.

- Operate the developed machine at a sieve inclination angle of between 10 to 15 degrees.

- Clean compost at a moisture content of about $40 \%$.

- Operate the developed machine at a feed rate of between 3.0 to 4.5 Mg/h.

\section{REFERENCES}

Awady, M. N. (1978). Tractor and farm machinery . Txt bk., Col. Ag., Ain Shams U.: 146-167.

Awady, M.N.; E. Y. Ghoneim and A.I.Hashish (1982). Asritical comprison between wheat combine harvesters under Egyptian conditions. R. S. No.1920, Ain-Shams Univ. Food and Agriculture Organization ( FAO.).

Klenin, N.I.; I.F. Popov and V.A. Sakon (1985). Agricultural machines. Theory of operation, computation of controlling parameters and the conditions of operation. Amerind publishing Co. PVT. Ltd., New Delhi.

Kurt,G. (1979). Engineering formulas. Third Ed. Mc Graw-Hill book Company. New York St. Lous San Francisco Montreal-Toronto.

Page, N.; J. Leonard and G. Clark (2005). Comparison of screening methods to refine MSW compost . Alberta Environment, Edmonton, Canada. BioCycle, 46(4): 57-58.

Robert R., K. Maarten ; B. W. George ;E. S. Mark ; L. R. Tom ; J. K. John ; R. G. Francis ; L. J. Lucien ; K. David ; W. M. Dennis ; A. J. Harry and F. B. William (1992). On-farm composting handbook. Northeast Regional Agricultural Engineering Service, 152 Kiley-Robb Hall, Cooperative Extension, Ithaca, NY 148535701, USA. 
Roth,L.O.; F.R. Crow and G.W.A. Mahoney (1975). An introduction to agricultural engineering. The AVI Pub. Co., Inc., West Port Conn.

William F. B. (2000). Compost quality standards \& guidelines. New York State Association of Recyclers. Woods End Research Laboratory, Inc. P: $1-42$.

\section{الملخص العربيى \\ تصنيع وتقييم أداء وحدة محلية لتنظيف الكمبوست لتعظيم جودة المنتج التهائح وده مده

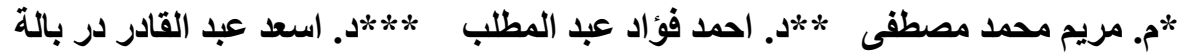

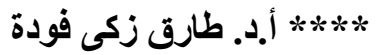

يعتبر تر اكم مخلفات المحاصيل الحقلية من أهم المشاكل الحيوية التي تمثل خطر إندا على إنى

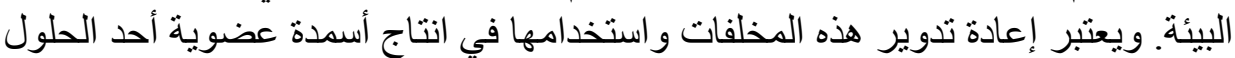
للتخلص منها بطريقة آمنة. وتعتبر عملية غربلة السماد الناضج من أهم العمليات التى يجب أنس أن تجرى لإنتاج الأسمدة

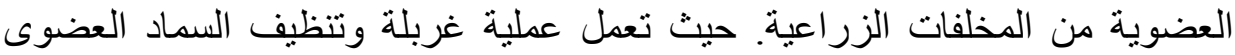

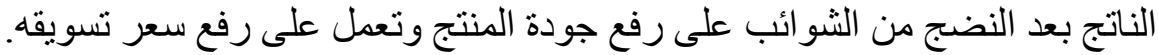
لذا فقد اتجه هذا البحث الى محاولة تصنيع وحدة محلية لغربلة وتنظيف الكمبوست

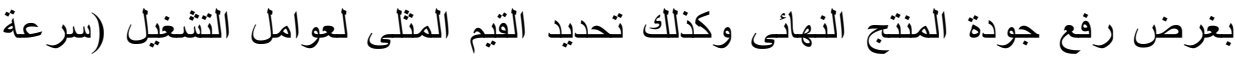

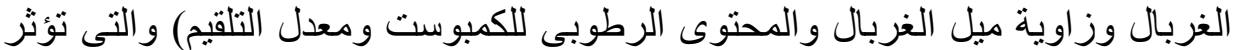

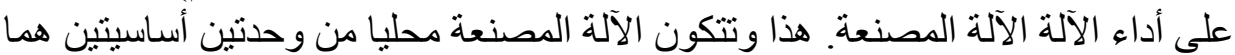

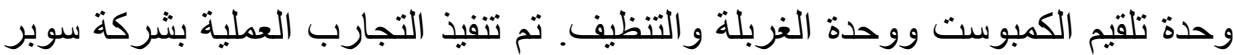

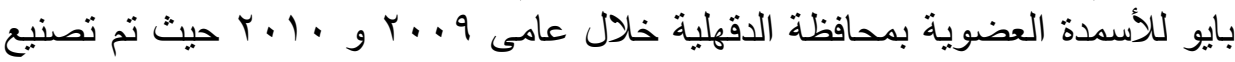

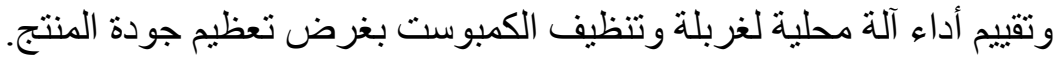



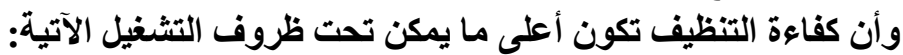

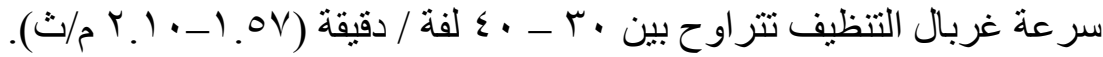

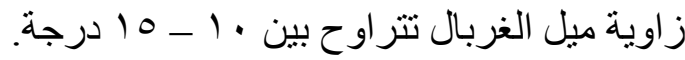

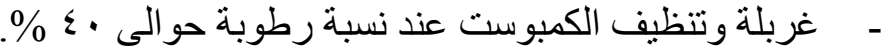

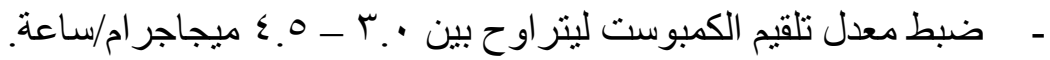

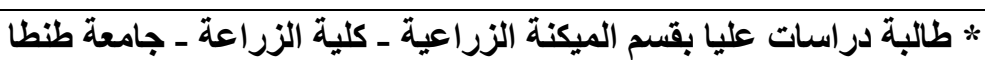

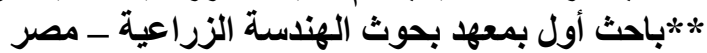

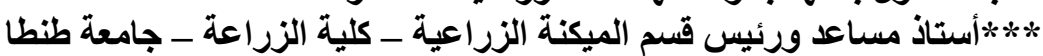
*** ** أستاذ ووكيل الكلية لشئون خدمة المجتمع وتنمية البيئة ـ كلية الزراعة الزعة ـ جامعة طنطا 